\title{
Buttocks lift for tight thighs
}

\author{
Aurelio Vazquez-Salisbury MD, Robert A Ersek MD FACS
}

Austin, Texas

\begin{abstract}
A Vazquez-Salisbury, RA Ersek. Buttocks lift for tight thighs. Can J Plast Surg 1996;4(1):59-63. Existing techniques for tightening loose or excess skin of the lateral thighs have frequently resulted in conspicuous scars on the hips, groin creases or medial thighs. A technique is described by which a wedge of subcutaneous tissue and skin, $10 \mathrm{x}$ $20 \mathrm{~cm}$, can be removed from the inner thigh and central buttocks crease where the scar can be completely hidden. A series of six patients, all seen at different stages after surgery, is presented.
\end{abstract}

Key Words: Buttocks lift, Skin, Subcutaneous tissue, Tight thighs

\section{Redrapage du siége pour des cuisses plus fermes}

RÉSUMÉ: Les techniques employées actuellement pour raffermir la culotte de cheval ont souvent donné lieu à des cicatrices inélégantes au niveau des hanches, du pli des aines ou du milieu des cuisses. Nous décrivons ici une technique au moyen de laquelle un coin de tissu cutané et de peau de $10 \mathrm{~cm}$ x $20 \mathrm{~cm}$ peut être excisé à partir de l'intérieur de la cuisse et de la raie des fesses où la cicatrice se trouve tout à fait camouflée. Une série de six patientes, toutes vues à différents stades suivant la chirurgie, est présentée ici.

Body sculpturing by liposuction in combination with surgery began as a lifesaving procedure for patients with morbid obesity (1). Techniques have been refined so that substantial amounts of skin and fat can be removed and the entire body virtually remodelled by these excisions. All removals, however, leave a conspicuous scar. The development of groin crease, buttocks crease and medial thigh incisions by Baroudi (2), Pitanguay (3) and others have improved our ability to reshape this region. The advent of liposuction in 1980 made possible the subcutaneous excision of vast amounts of fat and created a further need for thigh and buttock lifting. The excellent anatomical clinical work of Lockwood (4) and Markman (5), have added a whole new dimension to lifting of the thighs. All of these methods, however, leave noticeable scars that may spread and migrate in time.

We have devised a simple excision method (6) whereby vast amounts of skin and subcutaneous tissue can be taken from the central portion of the buttocks and medial 
thigh and the scar hidden within the innermost creases so that no visible evidence of this excision exists.

\section{METHODS AND MATERIALS}

The patient is marked in a standing position where retraction of the skin and subcutaneous tissue medially and posteriorally illustrates the amount to be removed. The incision is then marked from approximately the level of the coccyx along the inner surface of the buttocks fold medially and inferiorly to the labia majora. The full thickness section of skin and subcutaneous tissue, measuring about $25 \times 10 \mathrm{~cm}$, can be removed. Minimal or no undermining is necessary and the entire subcutaneous tissue can be approximated with $3 / 0$ absorbable stitches in the subcutaneous tissue and a running 5/0 polyglycolic acid suture in the skin. The skin incision is then reinforced with suture strips. No drains are necessary.

\section{RESULTS}

Case 1: This case involved a 33-year-old female who had previously had liposuction on two occasions to contour her medial and lateral thighs precisely. She was quite pleased with the size and shape, but felt the skin was too lax and loose and the buttocks crease was redundant, ie, the fold was too pronounced. A section of the skin and subcutaneous tissue measuring $6 \times 15 \mathrm{~cm}$ was removed. Figures 1-6 show the patient before, during and after her first, second and third buttocks lift procedures.

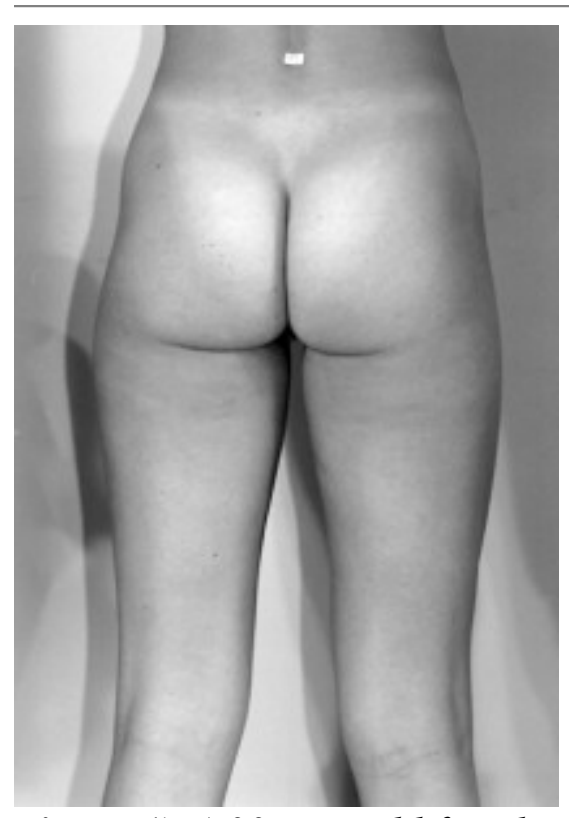

Figure 1) A 33-year-old female (case 1) at initial presentation, before treatment 


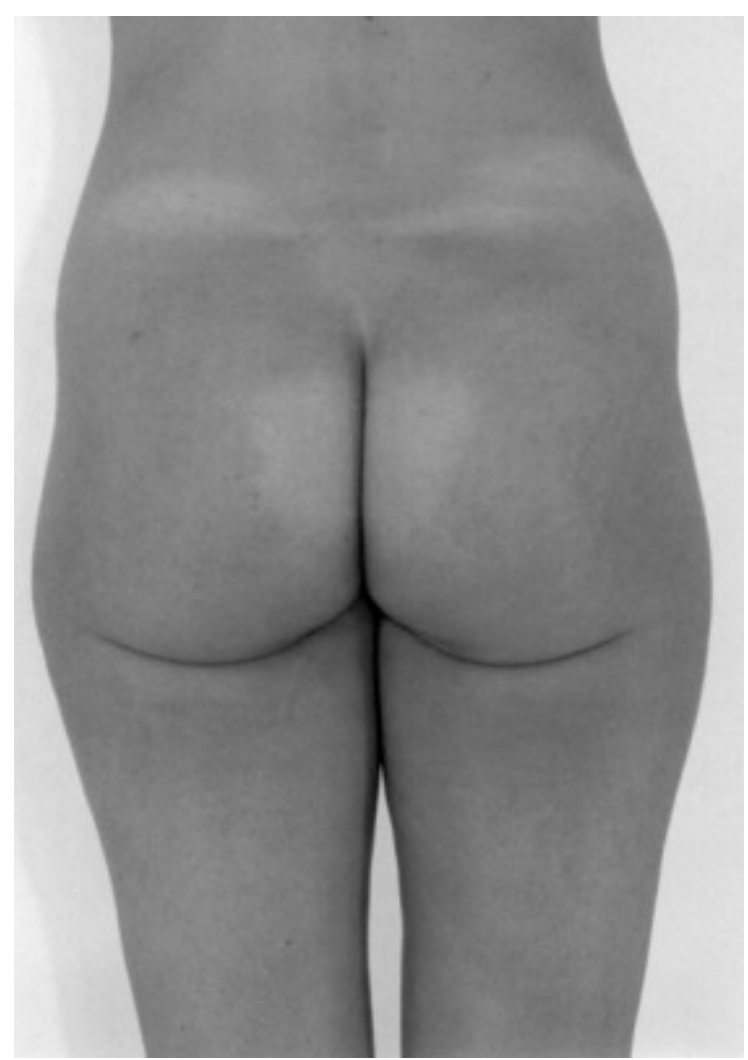

Figure 2) Case 1 seen after two sessions of suction totaling $1800 \mathrm{~mL}$, seven years and one baby later after first visit 


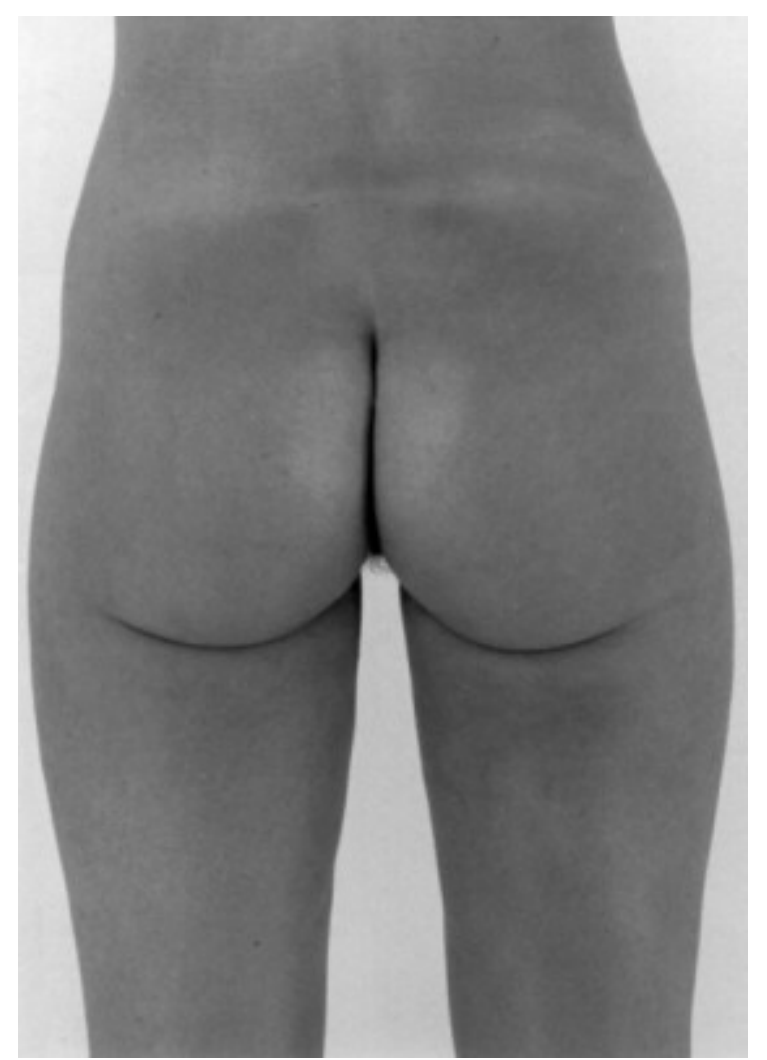

Figure 3) Case 1 after an additional $500 \mathrm{~mL}$ of suction from thighs, abdomen, buttocks and her first buttocks lift

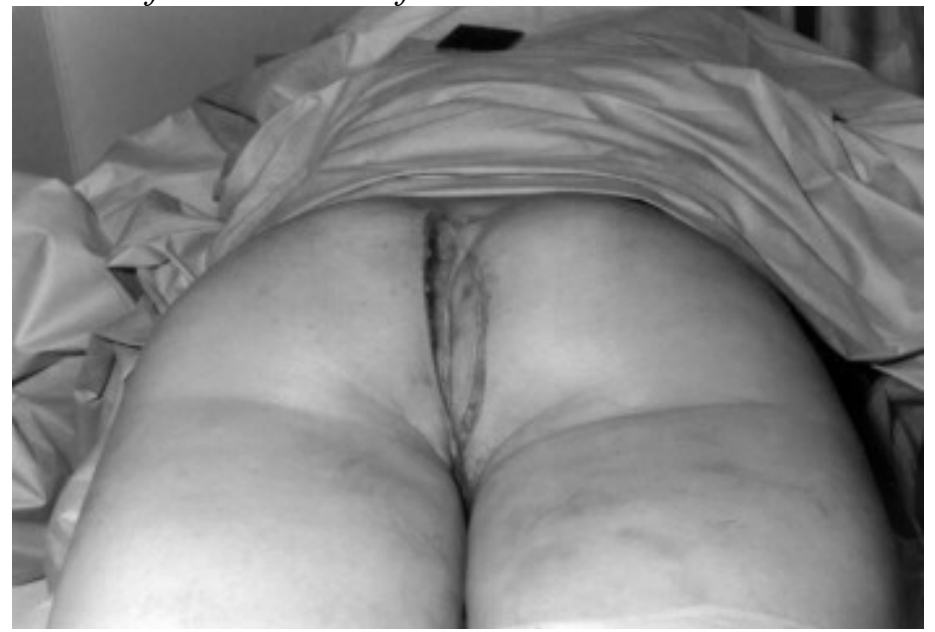

Figure 4) Case 1 seen during buttocks lift; one full thickness wedge of skin was removed from each buttock measuring $5 \times 15 \times 4 \mathrm{~cm}$ 


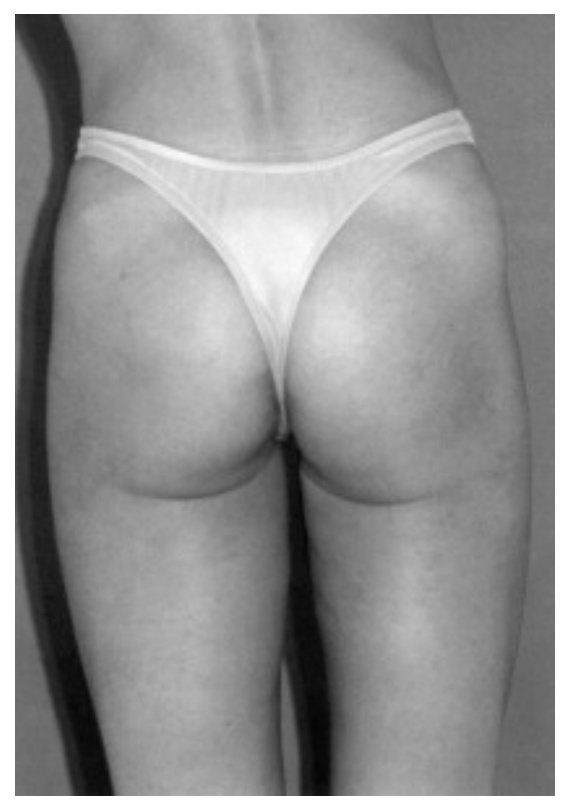

Figure 5) Case 1 after second saddle lift and an additional $300 \mathrm{~mL}$ of suction

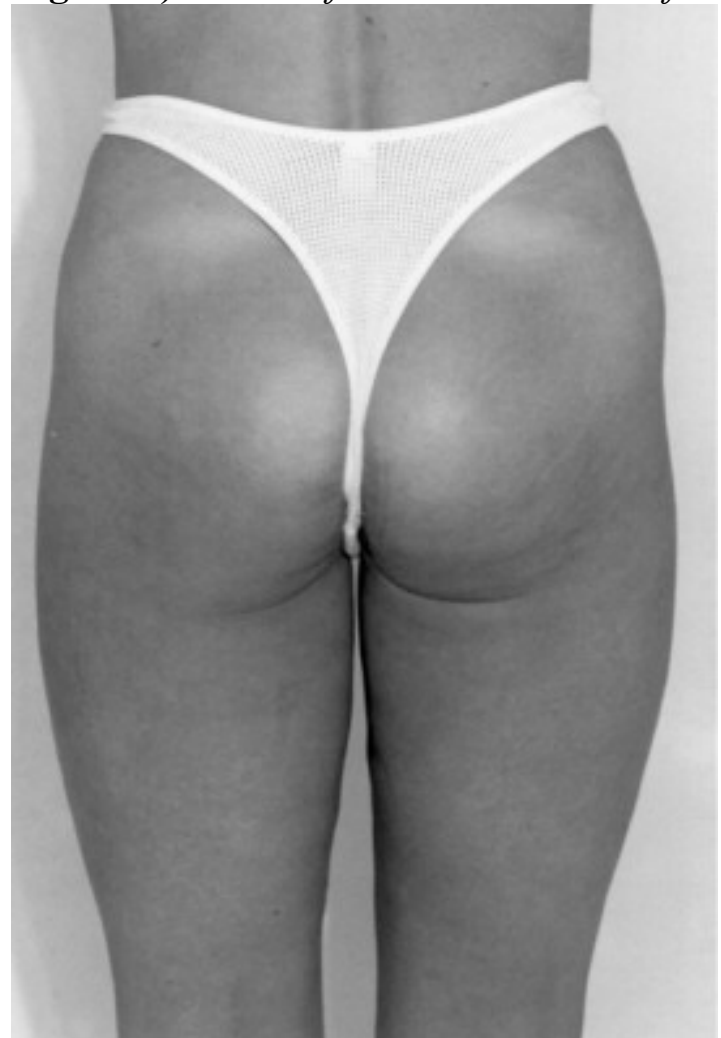

Figure 6) Case 1 after third and final saddle lift and $275 \mathrm{~mL}$ of suction totalling $2875 \mathrm{~mL}$

Case 2: This case involved a 30-year-old female who had previously had suction on one occasion to refine her thighs, abdomen and buttocks. The patient complained that the buttocks fold was too noticeable. A total of $250 \mathrm{~mL}$ was suctioned from the thighs and buttocks and an excision of skin and subcutaneous tissue, measuring $8 \times 18 \times 5 \mathrm{~cm}$, was 
performed. Figures 7-9 show the patient before and after the procedures, and showing the incisions.

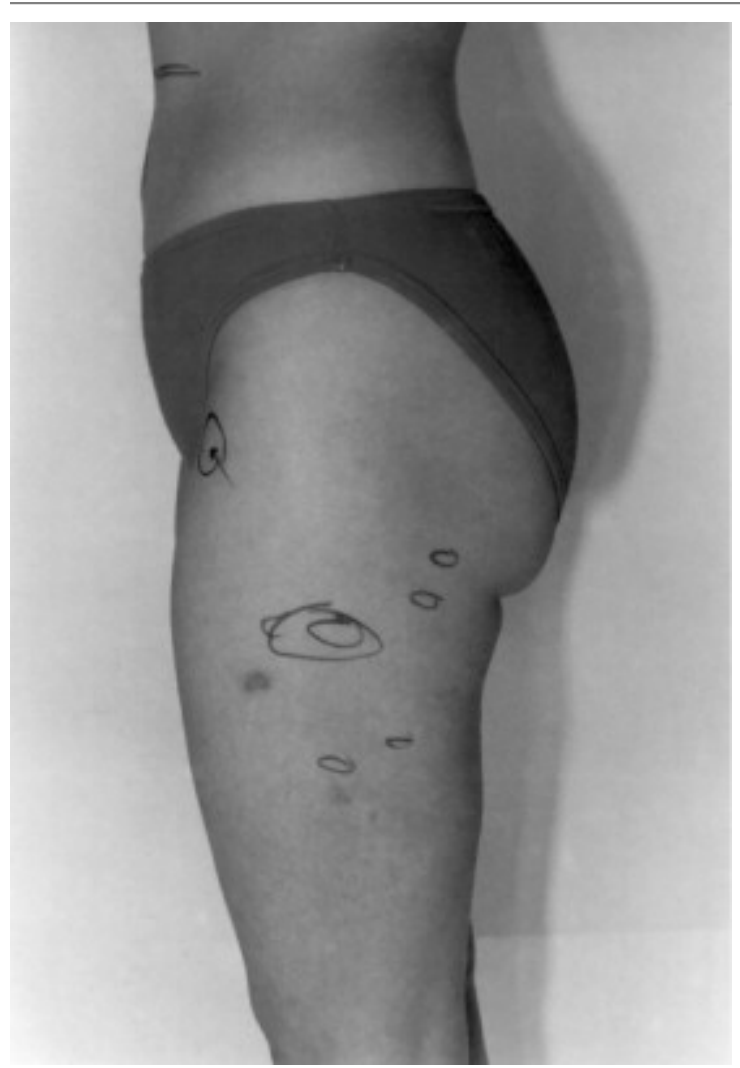

Figure 7) A 30-year-old female (case 2) who had suction performed previously, but complained the buttocks fold was too noticeable 


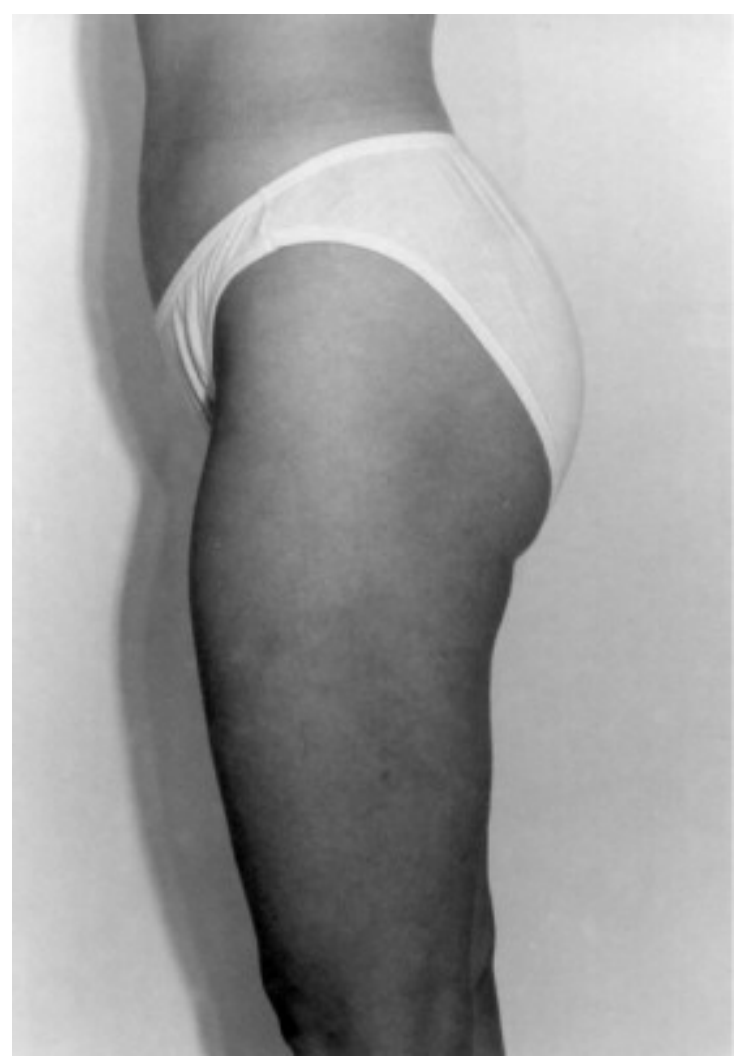

Figure 8) Case 2 after $250 \mathrm{~mL}$ of suction and a buttocks lift, six weeks postoperatively

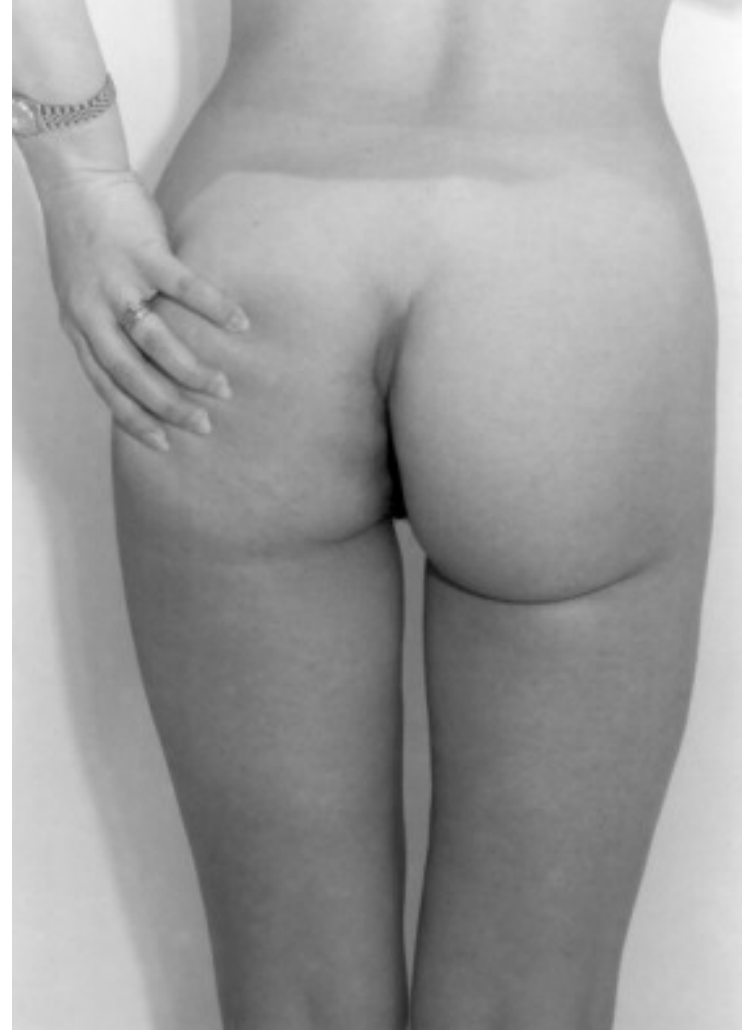

Figure 9) Case 2 showing her incisions that are almost unnoticeable in the buttocks crease 
Case 3: This case involved a 35-year-old female who had previously had facial surgery with us and consulted us regarding the ptotic appearance of her buttocks, which persisted despite continuous dieting and exercising. A full thickness wedge of skin and subcutaneous tissue measuring $3 \times 18 \times 3 \mathrm{~cm}$ was removed from both buttocks. Figures 10 and 11 show the patient before and six weeks after the procedures.

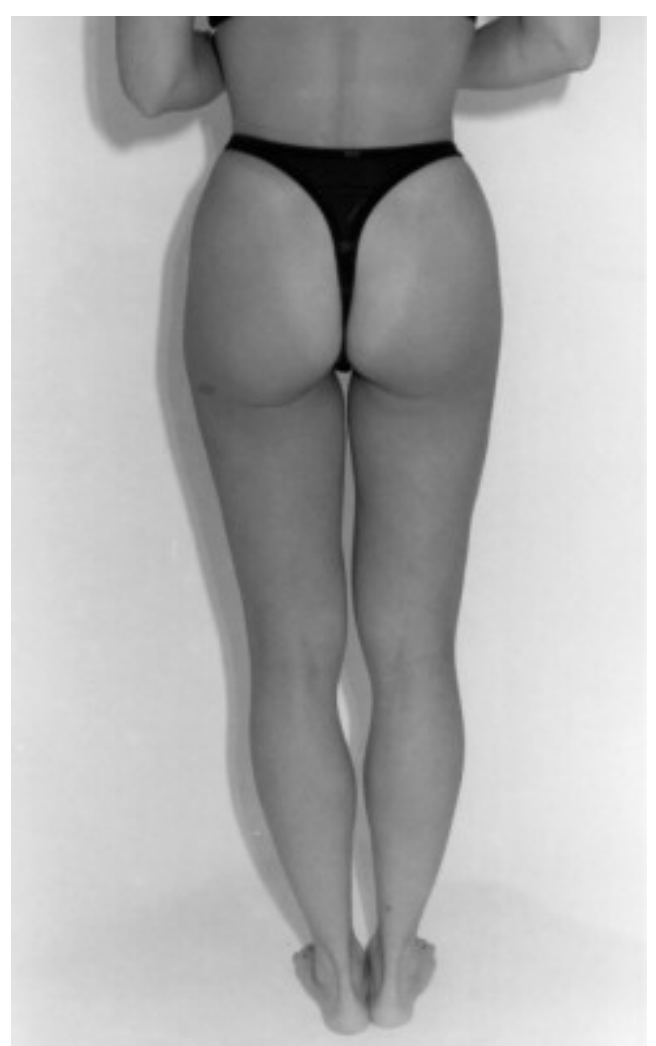

Figure 10) A 34-year-old female (case 3) who complained her lower buttocks appeared loose, despite dieting and exercise 


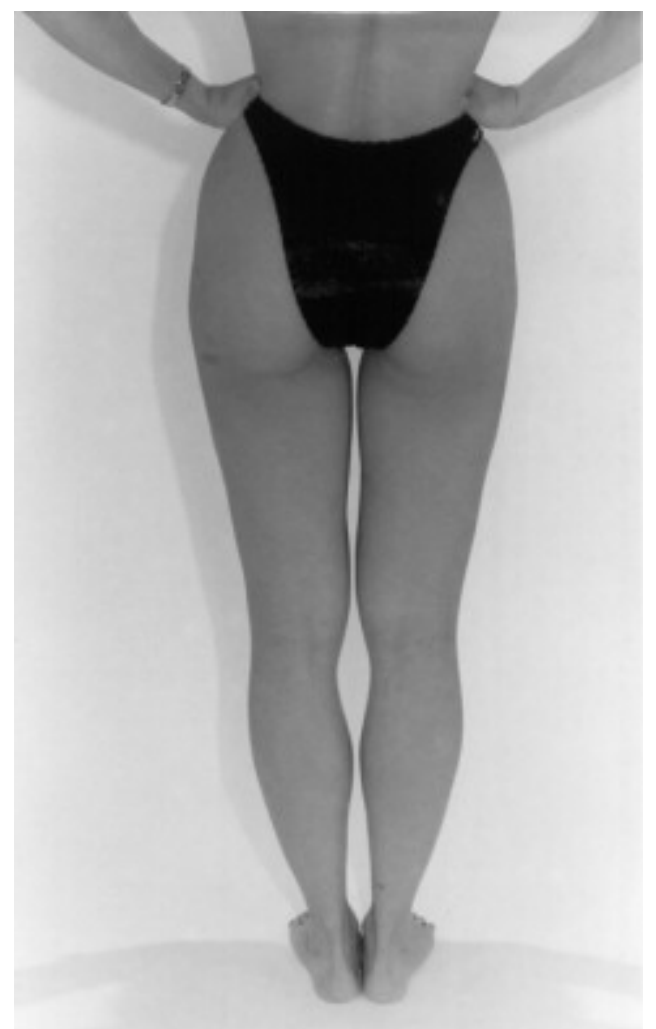

Figure 11) Case 3 after $200 \mathrm{~mL}$ of suction and a buttocks lift, six weeks after procedures

Case 4: This case involved a 32-year-old female who initially consulted us due to her large hips and buttocks, a trait common in the women of her family. After a total of 12.4 $\mathrm{L}$ of subcutaneous tissue was removed in four sessions over a two year period, her figure was much improved. Two years later she returned stating that the skin on her buttocks and thighs was loose and wished it improved. Figures 12-14 show her before treatment, after four sessions of suction and after an additional $1050 \mathrm{~mL}$ of suction and an excision of $10 \times 20 \times 5 \mathrm{~cm}$ of subcutaneous tissue and skin. In this patient, visible scars at the top of the crease are a result of extending lift incisions too far. She will have a revision to correct this problem. 


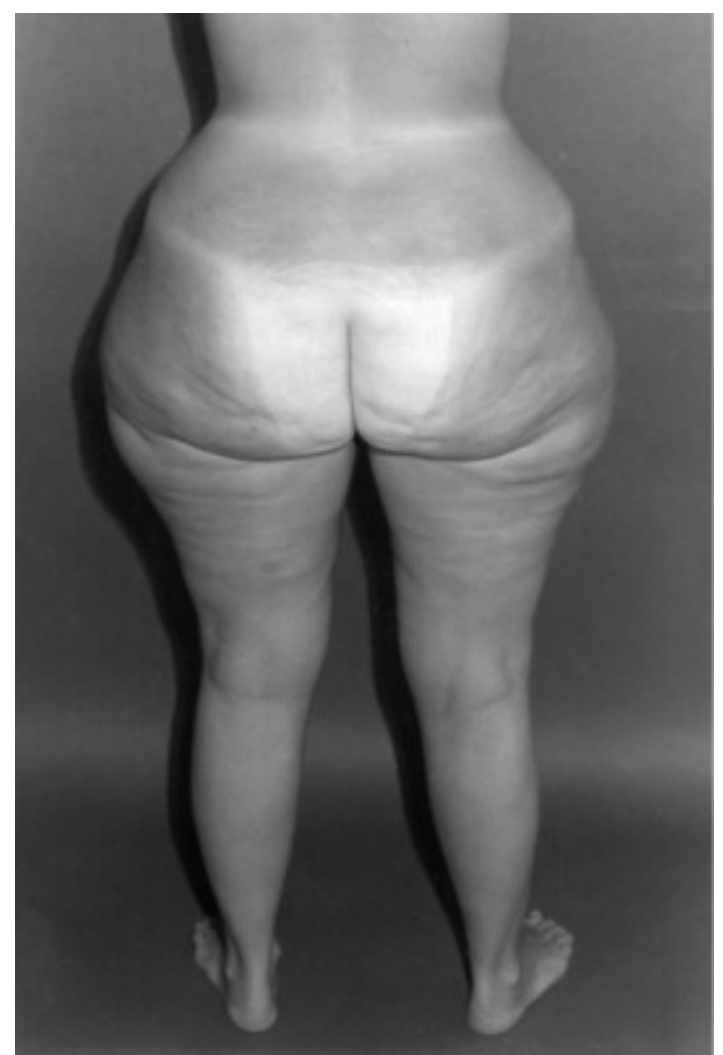

Figure 12) A 32-year-old female (case 4) who was concerned about her prominent hips and thighs 


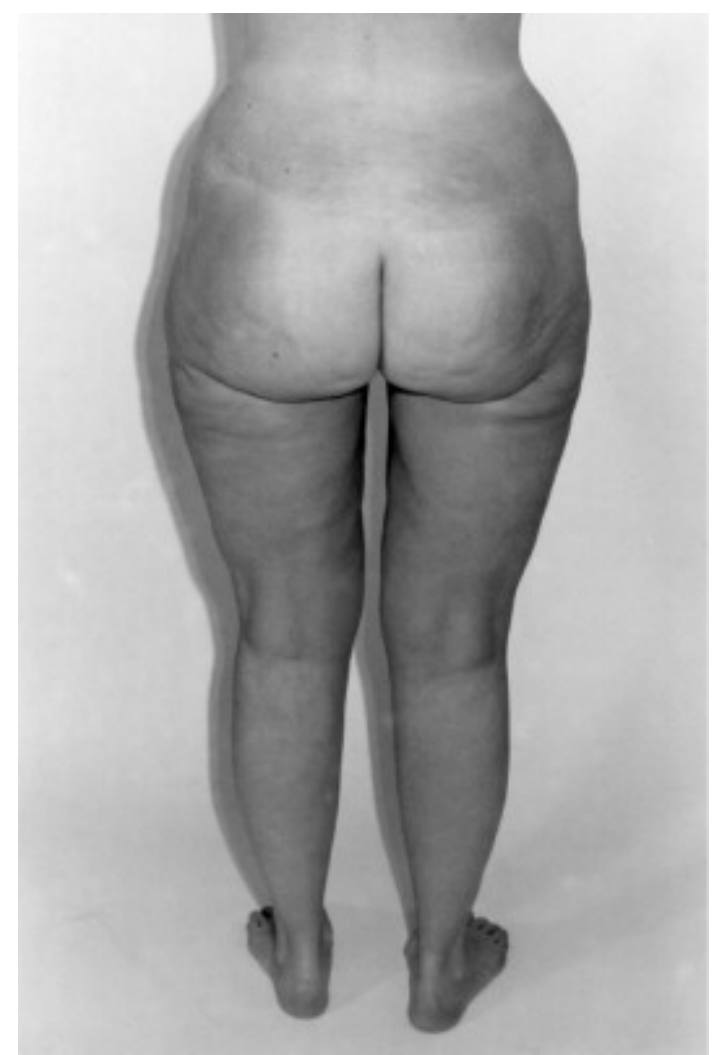

Figure 13) Case 4 after removal of 12.4 L of suction in four sessions over a two year period

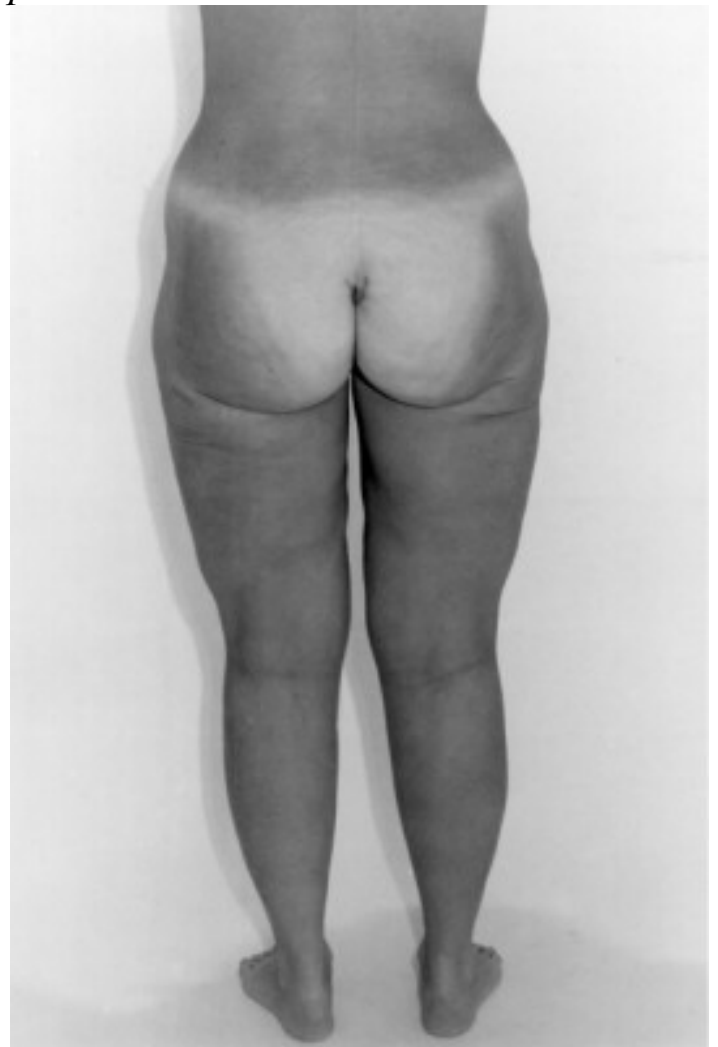

Figure 14) Case 4 after an additional $1050 \mathrm{~mL}$ of suction and a buttocks lift. In this 
patient, visible scars at the top of the crease are a result of extending lift incisions too far. She is scheduled for a scar revision to correct this problem

Case 5: This case involved a 41-year-old female who consulted us regarding the shape of her thighs and buttocks. A total of $2850 \mathrm{~mL}$ of fat was removed from her hips, thighs, flanks and abdomen. Tissue excision for buttocks lift was $6 \times 20 \times 4 \mathrm{~cm}$. Figures 15 and 16 show the patient before and five weeks after the procedures.

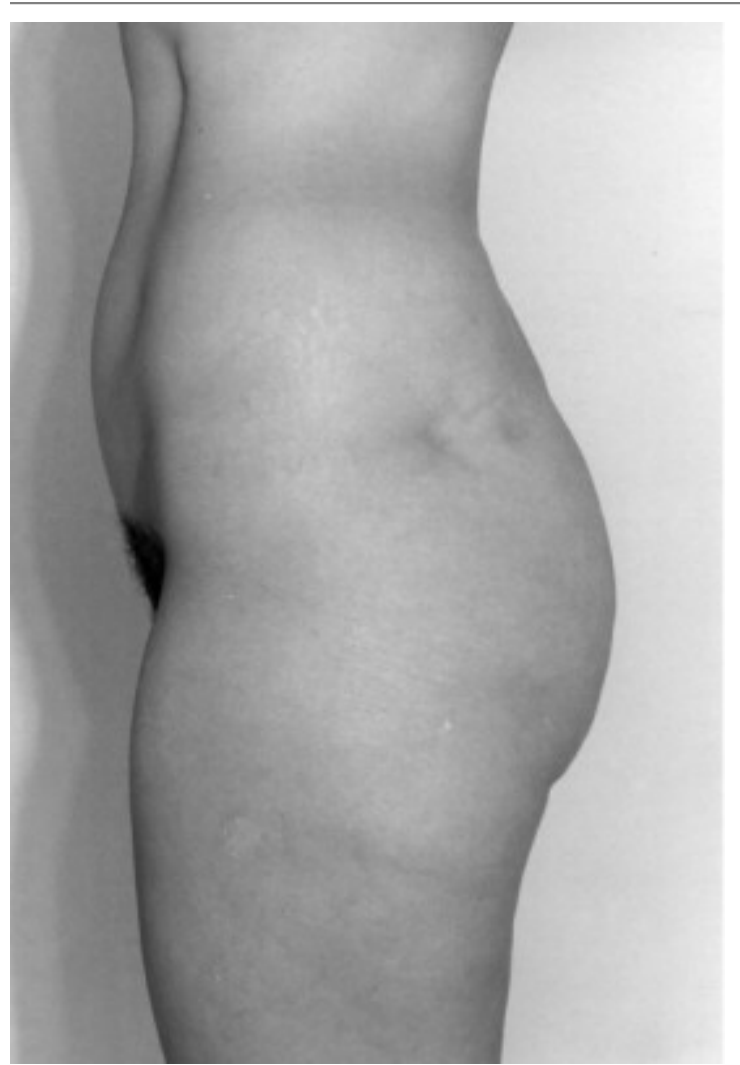

Figure 15) A 41-year-old female (case 5) who was concerned about the shape of her thighs and buttocks 


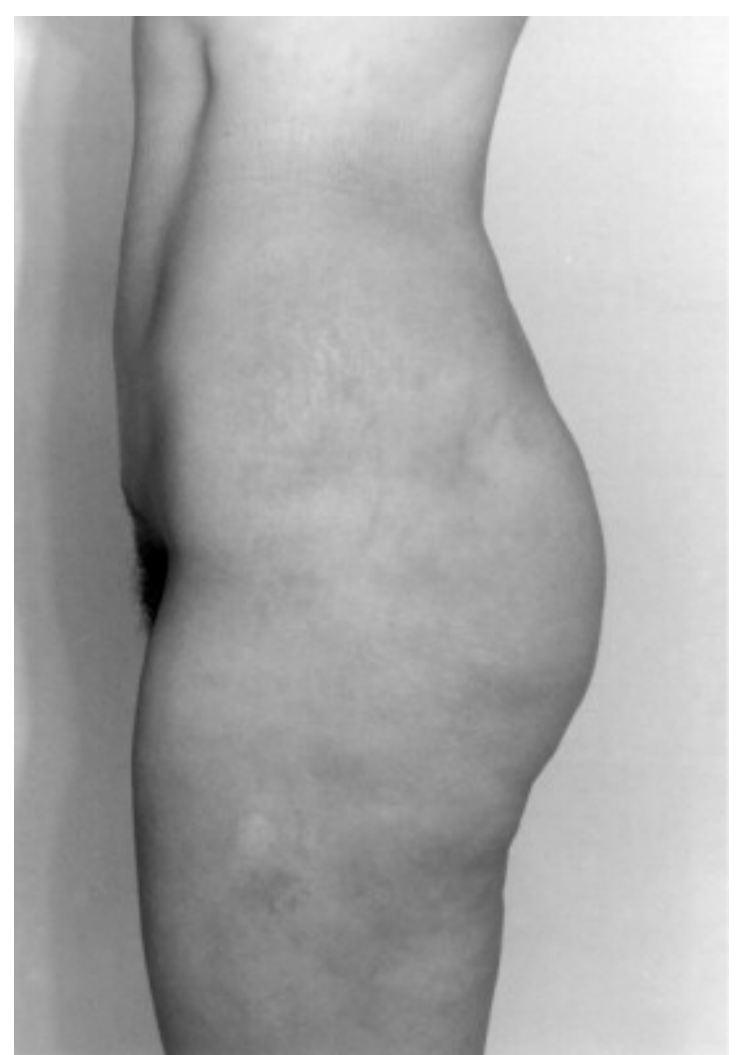

Figure 16) Case 5 at five weeks after $2850 \mathrm{~mL}$ of suction and a buttocks lift; some swelling and bruising is still present. Improvement is now noticeable

Case 6: This case involved a 32-year-old female who had recently lost about $100 \mathrm{lb}$ (45 $\mathrm{kg}$ ). She had loose redundant skin around her abdomen, waist, thighs, arms, buttocks and breasts. She had a breast reduction, an equatorial lipectomy, arm suction and a saddle lift. Figures 17-20 show before and after views of her profile and posterior. 


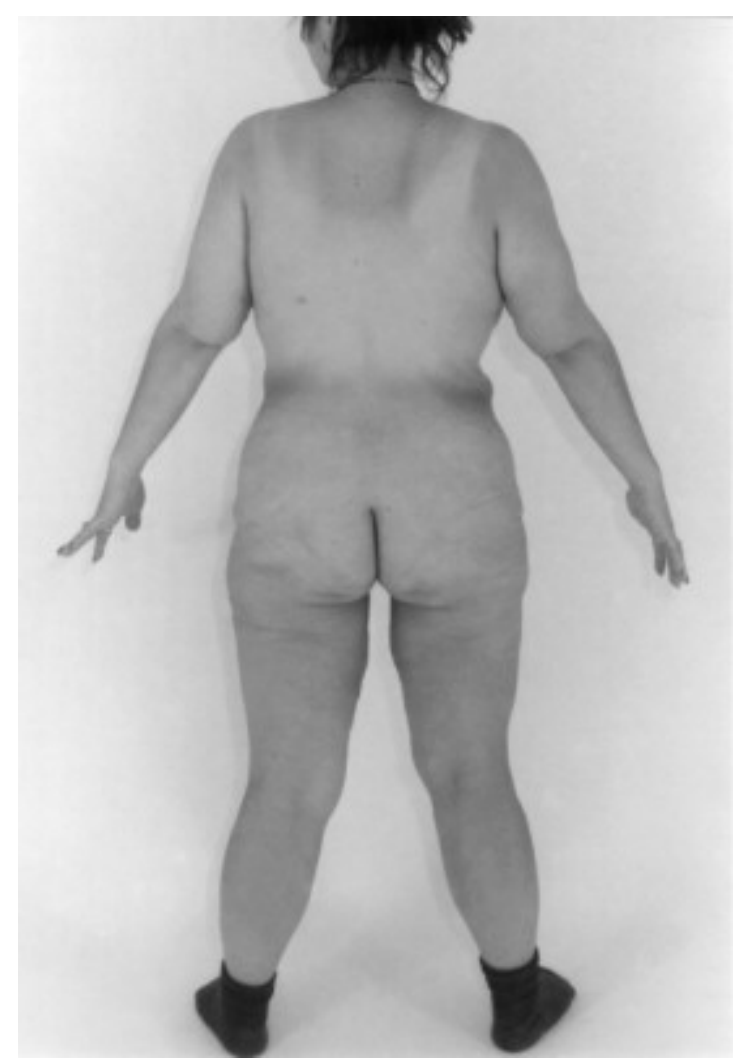

Figure 17) A 32-year-old female who had lost $100 \mathrm{lbs}(45 \mathrm{~kg}$ ) and wanted the loose, troublesome skin around her hips, thighs, buttocks and breasts removed. She is seen after $1.5 \mathrm{~L}$ of suction and an abdominal lipectomy totalling about $6 \mathrm{~L}$ 


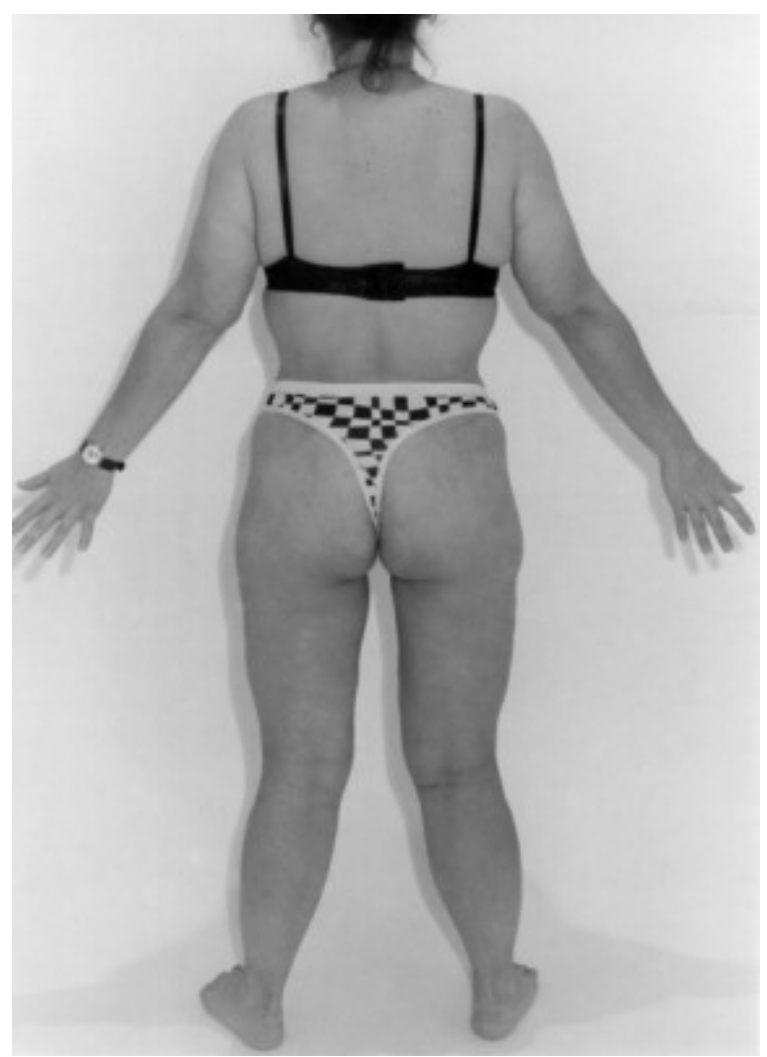

Figure 18) Case 6 seen at eight weeks after saddle lift

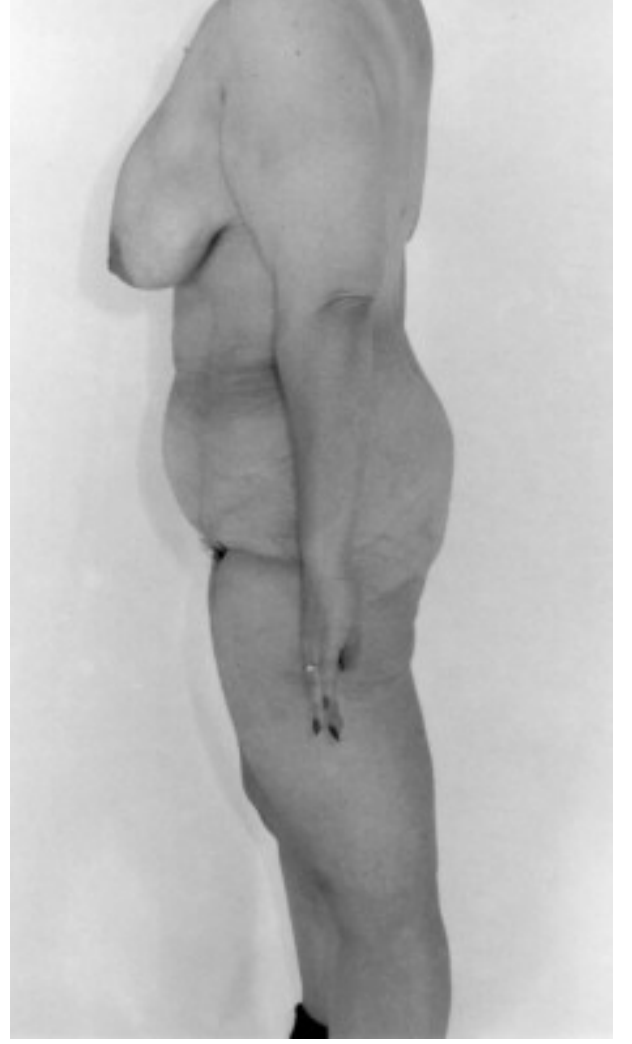

Figure 19) Lateral preoperative view of case 6 


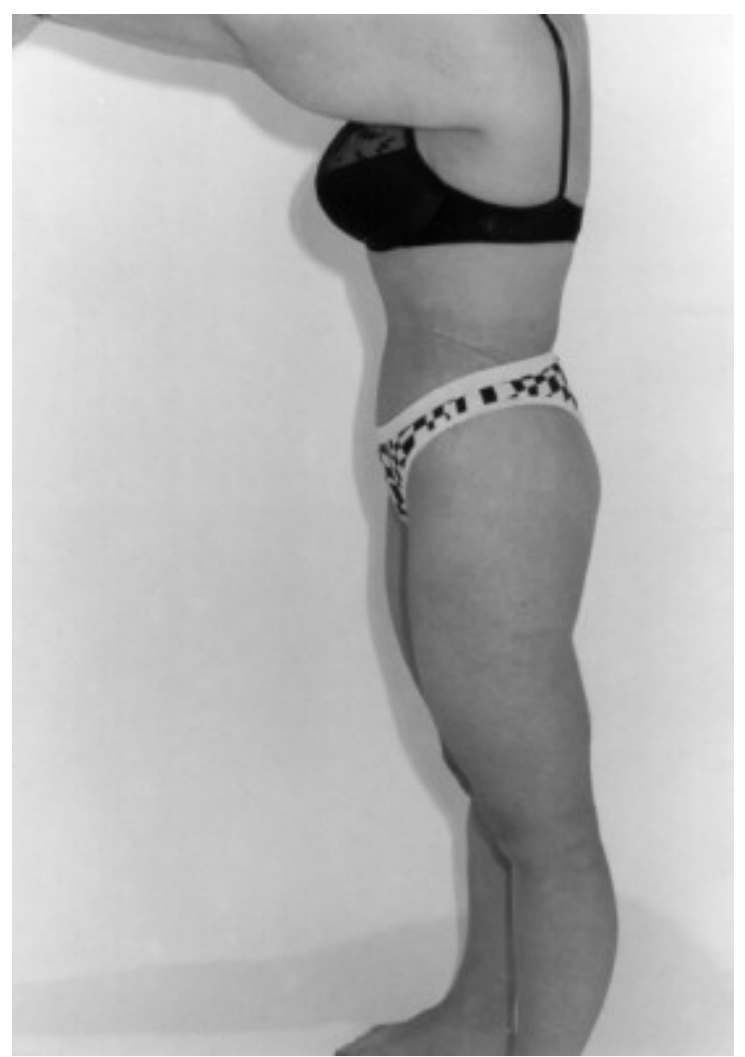

Figure 20) Lateral view of case 6 after buttocks lift and reduction mammaplasty

\section{CONCLUSION}

A large amount of skin and subcutaneous tissue can be removed from the medial portion of the buttocks crease, very close to the midline without damage to surrounding structures, and the incisions can easily be concealed if done carefully.

ACKNOWLEDGEMENTS: The authors wish to thank the following individuals for their assistance associated with this work: Gerry Ersek and Stephanie Salisbury for their loyal support; Stephanie Salisbury for her artistic contributions; Cheryl Green for her patient preparation of this manuscript; April Ivy, Kelly McQuerns-Martin, and Rhonda Wilder for their contribution in the development, application, and record keeping; Stewart Bates for his photographic contributions.

\section{REFERENCES}

1. Illouz YG. The Origin of Lipolysis. In: Hetter GP, ed. Lipoplasty: The Theory and Practice of Blunt Suction Lipectomy. Boston: Little, Brown

2. Baroudi R, Carvalho CGS. Lifting of the inner third of the thigh. An analysis of immediate and mediate results (Spanish). Cir Plast Iber Lat Am 1981;7:275.

3. Pitanguy I. Trochanteric lipodystrophy. Plast Reconstr Surg 1964;34:280. 
4. Lockwood TE. Fascial anchoring technique in medial thigh lifts. Plast Reconstr Surg 1988;82:2.

5. Markman B, Barton, FE Jr. Anatomy of the subcutaneous tissue of the trunk and lower extremity. Plast Reconstr Surg 1986;80:248-53.

6. Ersek RA, Salsbury AV. Saddlelift for tight thighs. Aesthetic Plast Surg 1995;19:3413. 